УДК 336.71

DOI: https://doi.org/10.26642/jen-2020-4(94)-99-105

О.В. Лисенок, д.е.н., проф.

Національний університет харчових технологій

\title{
Теоретико-методологічні відмінності диверсифікації та сек'юритизації кредитного портфеля банку
}

У статті досліджується сутність диверсифікаиї як основного методу управління кредитною діяльністю вітчизняних банків, під час використання якої враховується здатність портфеля кредитів зменшувати можливий ризик за умови врахування до нього різних за характеристиками та складом позик. У статті також зазначено, щзо диверсифікація дає змогу знизити не лише кредитний ризик, а й інші банківські ризики, які супроводжують загальний кредитний процес: ризик дострокового погашення, ліквідності, процентний, валютний та інші. Традиційна банківська теорія розглядає диверсифікацію як оптимальний спосіб ефективноі організації кредитної діяльності, при иьому найефективнішою вважається така позикова діяльність банків, яка є максимально диверсифікованою.

Проаналізовано, щчо кредитний портфель банків Украйни слабо диверсифікований $і$ дуже ризиковий, оскільки більше половини виданих кредитів вітчизняними банками зосереджено у Київській області та більше третини виданих позик знаходяться у торгівлі. У статті чітко виокремлено позитивні і негативні сторони диверсифікаџіï. Завдяки дослідженню процесу сек'юритизації доведено, щзо для вітчизняних банків вона є відносно новим видом банківськоі діяльності. Завдяки трансформачії неліквідних активів у ліквідні, сек'юритизачія зменшує портфельний кредитний ризик банківської установи, щзо дає можливість розглядати сек'юритизацію як процес перетворення неліквідних активів у иінні папери, тобто як один зі специфічних механізмів здійснення фінансово-економічної діяльності банків. У статті пропонується розрізняти три основні різновиди сек'юритизачї: класична сек'юритизація, синтетична сек'юритизація та сек'юритизачія бізнесу. У статті зазначено причини, чому украӥнські банки не поспішають застосовувати сек'юритизацію, а також ї̈ основні переваги порівняно з диверсифікачією активів.

Ключові слова: банк; диверсифікація активів; сек'юритизація активів.

Актуальність теми. Управління кредитною діяльністю банків є одним із основних напрямів наукових досліджень, адже кредитування завжди було й залишається пріоритетною економічною функцією банків. Тому визначення основних теоретико-методологічних відмінностей диверсифікації та сек'юритизації кредитного портфеля банків є необхідною умовою підвищення ефективності фінансовоекономічної діяльності банківських установ, раціональної організації їх кредитного процесу та зниження рівня кредитних ризиків.

Аналіз останніх досліджень та публікації, на які спирається автор. Вивчення економічної літератури свідчить, що кредитна діяльність банківських установ традиційно перебуває у центрі уваги науковців та економістів і залишається на сьогодні чи не найбільш дослідженим розділом банківської справи. Значний внесок у розробку питань кредитування банками зробили сучасні економісти Заходу Кристофер Ф. Блюмфілд, В.Лексис, Д. Мак-Ноток, Е.Рід, С.П. Роуз, Дж.Ф. Сінкі. Дослідженню теорії та практики організації кредитних відносин за умов наближення до міжнародних стандартів банківського кредитування сприяють праці вітчизняних вчених-економістів В.Л. Андрущенка, О.В. Васюренка, Я.В. Грудзевича, І.С. Гуцала, О.В. Дзюблюка, О.Т. Євтуха, Б.С. Івасіва, Т.Т. Ковальчука, В.Д. Лагутіна, I.М. Лазепка, Б.Л. Луціва, М.І. Мируна, В.І. Міщенка, А.М. Мороза, О.М. Петрука, О.В. Пернарівського, Л.О. Примостки, М.Ф. Пуховкіної, Б.І. Пшика, М.І. Савлука. Серед російських вчених праці І.Т. Балабанова, Ю.І. Коробова, В.І. Колесникова, О.І. Лаврушина, А.І. Ольшаного, Г.С. Панової, В.В. Кисельова, В.М. Усоскіна, В.А. Челнокова та ін.

Метою статті $\epsilon$ наукове теоретичне дослідження з питань удосконалення процесу диверсифікації та сек'юритизації кредитної діяльності банків для забезпечення стабільного функціонування вітчизняної банківської системи в цілому.

Викладення основного матеріалу. Спершу розглянемо диверсифікацію як основний метод управління кредитною діяльністю вітчизняних банків, під час використання якої враховується здатність портфеля кредитів зменшувати можливий ризик за умови врахування до нього різних за характеристиками та складом позик.

3 огляду на різноманітність ознак, характеристик і трактувань диверсифікації, дослідники не мають єдиної думки щодо іiі видів у кредитній діяльності [1-5]. Крім того, деякі автори пропонують диверсифікацією вважати лише розширення діапазону кредитування, тобто оновлення кредитного 
портфеля, в результаті чого з'являються нові банківські кредитні послуги й продукти [4, с. 445], а розподіл сукупного ризику кредитних вкладень належать до окремого способу регулювання кредитних ризиків - розподілу ризику [5, с. 444-445]. Найчастіше в теорії та практиці використовується диверсифікація у часовому, просторовому й продуктовому аспектах [3, с. 205-207], а також галузева, географічна й портфельна диверсифікації [6, с. 138-140].

Варто зауважити, що ефективна диверсифікація - це не просте додавання до портфеля додаткових кредитів, адже рівень кореляції їх доходів із доходами від позик, уже присутніх у портфелі, має бути низьким. Однак під час диверсифікації портфеля кредитів необхідно враховувати не лише взаємозв'язок доходів за кредитами, як зазначає О.Ковальов, але й взаємозв'язок їх ризиків [3, с. 207]. Тому передумовою ефективної реалізації процесу диверсифікації кредитного портфеля $\epsilon$ вкладення коштів у позики, які мають низький рівень кореляції доходів і ризиків. Необхідно також зазначити, що диверсифікація дає змогу знизити не лише кредитний ризик, а й інші банківські ризики, які супроводжують загальний кредитний процес: ризик дострокового погашення, ліквідності, процентний, валютний та інші.

Традиційна банківська теорія розглядає диверсифікацію як оптимальний спосіб ефективної організації кредитної діяльності, при цьому найефективнішою вважається така позикова діяльність банків, яка $\epsilon$ максимально диверсифікованою. Щодо цього зазначимо, що диверсифікація у системі кредитного ризик-менеджменту переважно розглядається як метод, який дає змогу знизити загальний ризик кредитного портфеля шляхом розподілу кредитних вкладень. Зокрема, фінансовий аналітик Д.Престбо звернув увагу на наявність лише позитивного ефекту від диверсифікації, навіть в умовах економічної кризи [7]. Такого ж погляду дотримуються і фахівці ФРС США [8]. Водночас не можна забувати, що Г.Марковітц у своїх дослідженнях акцентував на суперечливості позитивного ефекту від використання диверсифікації [9; 10]. На його думку, одним із моментів, що обмежує позитивний вплив диверсифікації, $є$ «наявність кореляції ризиків i доходів між одиницями, які диверсифікуються» [10, с. 102]. Проте усі позитивні і негативні ефекти від диверсифікації на сьогодні остаточно не досліджені. Як зазначає А.Саундерс: «поки що в літературі досягнуто певної згоди..., що вигода від диверсифікації потенційно висока. Та все змінюється...» [11, с. 181].

У зв'язку з цим зауважимо, що останнім часом з'являються дослідження, які доводять суперечливий вплив диверсифікації як з позиції внутрішньобанківської ефективності [12], так і з погляду системного ризику й ефективності діяльності банківської установи [13]. Виявити деякі негативні моменти щодо застосування диверсифікації у фінансово-економічній діяльності банків певною мірою допомагають емпіричні дослідження. Наприклад, В.Ачаря, на основі статистичних даних 105 банків, обгрунтував, що диверсифікація не забезпечує вищу ефективність і фінансову стабільність для банків. Як доводить дослідник, на практиці існує неефективна диверсифікація для банківської установи, що розширює свою кредитну діяльність у невідомих для неї галузях виробництва внаслідок високого рівня конкуренції та нестачі досвіду кредитування у цій сфері [12; 13]. Подібний висновок зробив німецький дослідник Е.Хайден, який запевняє, що особливих переваг у використанні диверсифікації немає, оскільки кожен різновид неефективної диверсифікації має певну властивість скорочувати банківські доходи. Крім того, позитивний вплив від застосування диверсифікації, на його думку, залежить від загального рівня ризику: доходи банків збільшуються лише за помірних рівнів ризику i, у випадку диверсифікації, за галузями виробництва [14].

Якщо проаналізувати диверсифікацію виданих кредитів вітчизняними банками за видами економічної діяльності, то можемо зробити висновок, що 33 \% кредитів видано у торгівлю, $25 \%-$ у переробну промисловість, $10 \%$ - у нерухомість. Диверсифікація кредитів за географічною ознакою показує, що найбільша частка кредитів зосереджена у Київській області - 56 \%, на другому місці Дніпропетровська область - $20 \%$, а на третьому - Одеська - 4 \% [15; 16].

Таким чином, стає очевидним, що кредитний портфель банків України слабо диверсифікований i дуже ризиковий, оскільки більше половини виданих кредитів вітчизняними банками зосереджено у Київській області й більше третини виданих позик знаходяться у торгівлі.

Отже, наукові дослідження й банківська практика доводять можливість виникнення як позитивного, так і негативного впливу диверсифікації:

- по-перше, диверсифікація використовується для нейтралізації внутрішніх, несистемних банківських ризиків [3, с. 207-208];

- по-друге, можливим $є$ збільшення трансакційних витрат унаслідок ускладнення параметрів i характеристик кредитного портфеля, що зумовлює зростання кількості супутніх ризиків [17, с. 343];

- по-третє, іноді погіршується контроль і якість управління кредитним портфелем через несприятливий вибір менеджерами напрямів кредитування, що скорочує доходи банку [12];

- по-четверте, надмірна диверсифікація призводить не до скорочення, а до збільшення кредитного ризику портфеля [18]; 
- по-п'яте, диверсифікація для банків із різним рівнем кредитного ризику може давати різну результативність: у банках, що проводять ризикову політику, диверсифікація зумовлює скорочення доходу внаслідок зростання суми банківських позик із високим ступенем ризику, а у банках із низьким рівнем ризику диверсифікація теж може призводити до неефективного співвідношення «ризику дохідності» або показувати мінімальний позитивний вплив [13].

Таким чином, під час диверсифікації кредитного портфеля існує ймовірність зростання кредитного ризику через неефективне застосування цього методу вищим керівництвом банку, що проявляється у:

- неадекватній оцінці кредитних проєктів або можливостей банку щодо їх реалізації, що може призвести до зростання інших «некредитних» ризиків;

- неефективних діях банківських менеджерів, які здійснюють диверсифікацію, особливо за просторовою, продуктовою й галузевою ознаками, що потребує глибоких знань ринку, особливостей галузі та специфіки діяльності самих підприємств;

- $\quad$ недоліках стратегії просування на ринок нового банківського кредитного продукту, а також у його недосконалості; напрямі.

недостатній кваліфікації та досвіді менеджерів під час роботи в новому для банку кредитному

Варто також зауважити, що диверсифікація кредитної діяльності може здійснюватися різними способами, зокрема шляхом прямого управління обсягом і структурою кредитного портфеля, а також за допомогою застосування спеціальних методів та механізмів управління банківськими ризиками. Перший напрям реалізується шляхом застосування різних видів диверсифікації, класифікація яких була наведена вище, а другий пов'язаний із використанням механізму сек'юритизації, формуванням резервів та методу лімітування.

Слід зазначити, що на відміну від інших методів управління кредитною діяльністю, сек’юритизація є відносно новим видом банківської діяльності. Звертаючись до історії, зауважимо, що на розвинених фінансових ринках сек'юритизація як окремий вид позабалансової діяльності банківських установ поширилася порівняно нещодавно - у 1980-1990-х pp., а темпи іï зростання у цей період становили 29,6 \% на рік [19, с. 744-752]. Упровадження інструменту сек'юритизації активів наприкінці 80-х рр. $\mathrm{XX}$ ст. спричинили такі економічні фактори:

- посилення конкуренції між фінансово-кредитними установами;

- зростання вартості залучення ресурсів;

- зниження операційної маржі, що призвело до зменшення доходів банківських установ;

- погіршення якості кредитних портфелів, унаслідок чого підвищилися вимоги регулюючих органів до розмірів власного капіталу банків [20, с. 22].

Про ефективність використання у фінансовій практиці інструменту сек'юритизації свідчить позитивний досвід багатьох зарубіжних країн, у яких вона використовується вже понад десять років і охоплює такі види кредитування, як: позики на придбання нерухомості, автомобілів, кредитні картки тощо. Завдяки сек’юритизації банківські активи ефективно працюють, генеруючи нові довгострокові кредити в реальний сектор економіки.

Варто зазначити, що засновником процесу сек'юритизації активів є США, де 3 метою створення вторинного ринку заставних цінних паперів у 1970 р. були утворені державні агенції, діяльність яких допомогла стандартизувати оформлення документів і угод про іпотеку. Сек'юритизація викликала інтерес також і з боку інших фінансово-кредитних установ, оскільки насамперед забезпечила новим фінансовим інструментарієм таких потенційних інвесторів, як страхові компанії та пенсійні фонди. Наприкінці 1980-х рр. сек’юритизацію запровадили в Канаді, Великобританії, Австралії, Японії; на початку 1990-х рр. - в усій Західній Свропі, Південно-Африканській Республіці, Гонконзі та Індії. У 2000-х рр. техніку сек'юритизації активів запровадили країни Центральної та Східної Свропи, Північної Африки і Близького Сходу. У 2003 р. перші операції із сек'юритизації кредитів здійснено в Польщі, Чехії, Казахстані, в 2004 р. - в Росії та Латвії, у 2005 р. - в державах Південно-Східної Азії [21].

Базельський комітет з питань банківського нагляду розглядає сек'юритизацію як структуровані угоди, в яких банки використовують кредитні деривативи, щоб передати кредитний ризик певного пулу активів третім особам, зокрема страховим компаніям, іншим банкам і нерегульованим особам [22]. У Міжнародних стандартах фінансової звітності № 39 «Фінансові інструменти: визнання і оцінка» сек’юритизація трактується як процес трансформації фінансових активів у цінні папери [23].

Подібно до того як розділяються думки фахівців міжнародних фінансово-кредитних установ, різняться думки й учених, які досліджують процес сек'юритизації. Зокрема Інго Фендер та Джанет Мітчелл вважають, що сек'юритизація - це процес, який об'єднує три основні етапи:

- об'єднання активів у пул за спеціально обраними ознаками;

- послаблення залежності оригінатора (табл. 1) від кредитного ризику шляхом передавання активів спеціальній установі;

- передача зобов’язань відповідно до ступеня ризику, який готові прийняти інвестори [24, с. 29]. 
Фактично й Ендрю Девідсон та Ентоні Сандерс дотримуються тієї ж думки; що сек'юритизація - це «процес формування пулів фінансових зобов'язань та надання їм форми, яка дає змогу фінансовим активам вільно обертатися серед значного кола інвесторів» [25, с. 16].

Таблиця 1

Функиії основних учасників процесу сек'юритизацฺї кредитів

\begin{tabular}{|c|c|}
\hline Учасник & Функція \\
\hline Банк-оригінатор & Формує пул кредитів \\
\hline $\begin{array}{l}\text { Спеціалізована юридична } \\
\text { компанія (SPV) }\end{array}$ & Купує пул кредитів у банку-оригінатора та емітує цінні папери \\
\hline $\begin{array}{l}\text { Гарант (банк, страхова } \\
\text { компанія) }\end{array}$ & $\begin{array}{l}\text { Надає фінансові ресурси у випадку, коли банк-оригінатор не в змозі } \\
\text { обслуговувати видані кредити }\end{array}$ \\
\hline Андерайтер & Оцінює й підтримує відповідні ціни емітованих цінних паперів \\
\hline Консалтингова компанія & $\begin{array}{l}\text { Надає консультації з питань оподатковування, } \\
\text { фінансової звітності тощо }\end{array}$ \\
\hline Рейтингова компанія & $\begin{array}{l}\text { На підставі аналізу якісно-кількісних характеристик пулу кредитів і } \\
\text { фінансової стабільності учасників процесу сек'юритизації визначає } \\
\text { рейтинг емітованих цінних паперів }\end{array}$ \\
\hline Інвестор & Вкладає грошові кошти в емітовані цінні папери \\
\hline
\end{tabular}

Враховуючи наведені визначення, можемо зробити висновок, що завдяки трансформації неліквідних активів у ліквідні, сек'юритизація зменшує портфельний кредитний ризик банківської установи. Таким чином, сек'юритизацію можна розглядати як процес перетворення неліквідних активів у цінні папери, тобто, як один зі специфічних механізмів здійснення фінансово-економічної діяльності банків.

Щодо цього зауважимо, що в міжнародній практиці пропонується розрізняти три основні різновиди сек'юритизації:

- $\quad$ класична сек'юритизація - це реалізація банком своїх активів спеціальній установі, яка фінансує придбання таких активів шляхом випуску цінних паперів на ринку капіталів (рис. 1);

- синтетична сек'юритизація - не передбачає продажу банком своїх активів, але банк передає ризик збитків за деякими активами спеціальній установі, за що сплачує ій премію або певну грошову суму;

- сек'юритизація бізнесу - це фактично кредит, який забезпечується всіма активами, що генеруються певною компанією [26; 27].

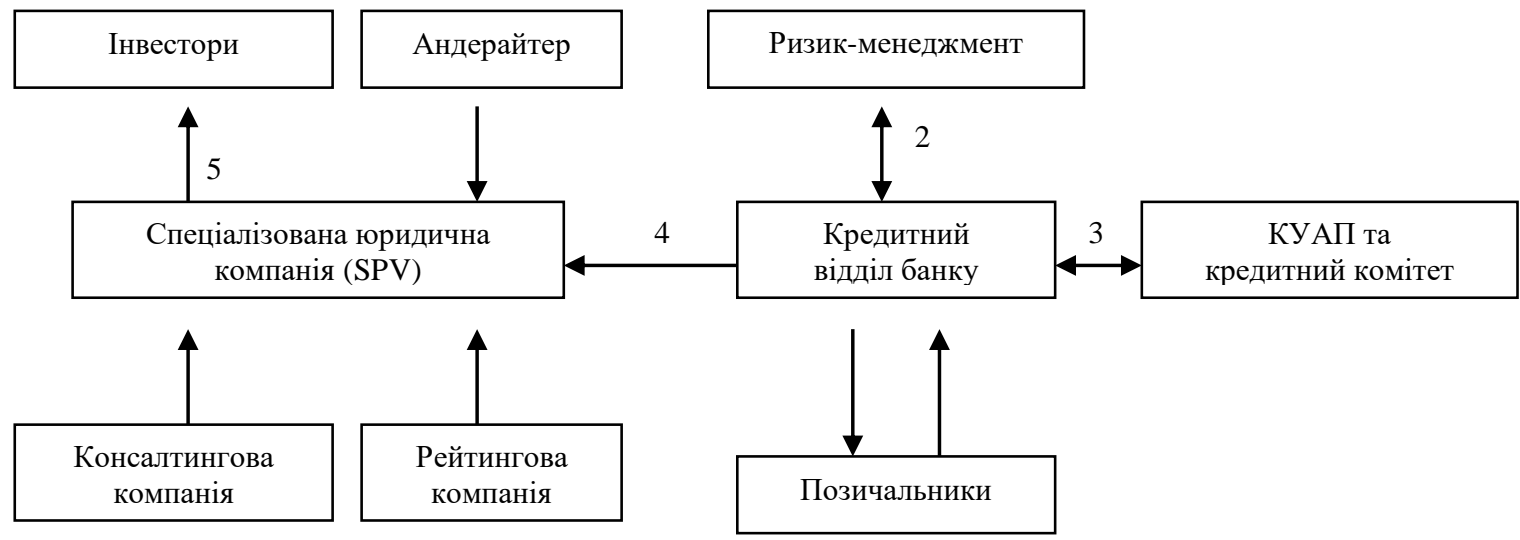

1. Видача та обслуговування кредитів.

2. Кредитний відділ банку разом із відділом ризик-менеджменту формують пул однорідних кредитів.

3. На спільному засіданні кредитного комітету і комітету з управління активами та пасивами розглядається інформація щодо сформованого пулу кредитів і ухвалюється рішення щодо проведення сек'юритизації, яке затверджується правлінням банку та спостережною радою.

4. Кредитний відділ банку передає пул активів до спеціалізованої юридичної компанії (SPV).

5. Емісія і розміщення іпотечних цінних паперів (облігацій)

Рис. 1. Процес здійснення сек'юритизаџії кредитів за допомогою класичного способу [20, с. 24] 
Зауважимо, що за класичною схемою сек’юритизації у березні 2007 р. ПАТ «Приватбанк» реалізував операцію, яка стала однією з найбільших у Східній Свропі, з випуску єврооблігацій на суму 180 млн дол. США, що були забезпечені іпотечними кредитами. До портфеля увійшло близько 10 тис. кредитів позичальників із різних регіонів України, причому середня величина одного кредиту становила приблизно 17 тис. дол. США. Висока якість іпотечного портфеля ПАТ «Приватбанку» забезпечила високий рейтинг єврооблігацій - він перевищив рівень інвестиційного рейтингу України. Основними інвесторами були банки й інвестиційні компанії з Свропи та Північної Америки, причому британські інвестори викупили 28 \% випуску, німецькі та австрійські - по 21 \%. У пулі інвесторів цього випуску взяли участь також французькі, португальські, російські, італійські, грецькі й канадські інвестиційні банки та компанії. На думку експертів, саме завдяки успішній операції сек'юритизації іпотечних активів ПАТ «Приватбанк» зміг зменшити відсоткові ставки за кредитами на купівлю житла і таким чином покращити свої конкурентні позиції на іпотечному ринку [20, с. 25].

Звертаючись до різновидів сек'юритизації, варто зауважити, що під час застосування будь-якого 3 методів сек'юритизації банк отримує значні переваги:

- замість довгострокових активів банківська установа вже отримує ліквідні кошти, які можна використовувати для фінансово-економічного розвитку чи здійснення наступних кредитних операцій;

- розширюється коло потенційних інвесторів;

- знижується рівень процентного та кредитного ризиків, а також ризику втрати ліквідності, оскільки сек'юритизація перерозподіляє зазначені банківські ризики між банківською установою, інвестором і посередником;

- підвищується виконання діючих нормативів фінансово-економічної діяльності;

- банк позиціонує себе як фінансову установу, що спроможна працювати зі складними фінансовими інструментами.

Таким чином, процедура сек'юритизації активів дає змогу банкам здійснювати трансферт кредитного ризику, а також процентного і ризику дострокового погашення кредиту, тому сек'юритизація знижує загальний рівень ризикованості банку та покращує якість його кредитів.

Висновки та перспективи подальших досліджень. Отже, враховуючи усе викладене вище, можемо зробити висновок, що сучасний стан управління кредитною діяльністю банків піднімається на нову еволюційну сходинку свого розвитку. Поряд із застарілими, добре відомими методами й інструментами, такими як: диверсифікація, лімітування, створення резервів, у процес управління кредитною діяльністю інтегрується сек'юритизація, яка революціонізує застосовувані на практиці банківські технології. У зв’язку з цим зазначимо, що вивчення нових методів управління кредитною діяльністю має велике значення для української банківської системи, адже, враховуючи усю специфіку фінансово-економічної діяльності вітчизняних банків, певні елементи міжнародного досвіду з банківської справи можна використати i в Україні. Проте зауважимо, що більшість українських банків не поспішає сек’юритизувати свої активи і це можна пояснити кількома причинами, наведеними нижче, подолання яких дасть можливість створити ефективний механізм сек'юритизації кредитів в Україні.

По-перше, нерозвинута законодавча база, пов'язана 3 нормативним регулюванням сек'юритизації активів, яка вимагає вирішення низки правових питань та узгодження їх 3 корпоративним, податковим та банківським законодавством. Сьогодні сек’юритизація не є суб'єктом спеціалізованого вітчизняного законодавства, а тому бракує уніфікованої документації щодо оформлення таких операцій, оскільки не визначено правовий статус спеціалізованої юридичної компанії та не з'ясовано специфіку оподатковування таких операцій. Актуальними залишаються й питання щодо створення закону, який би регламентував здійснення усіх основних видів сек’юритизації активів.

По-друге, в Україні немає ефективної інфраструктури фінансового та фондового ринків. Нестача ліквідних фінансових інструментів, їх неефективність та негнучка податкова система гальмують поширення та розвиток механізму сек'юритизації активів.

По-третє, вітчизняним банкам бракує законодавчого чи нормативного алгоритму формування пулів 3 однорідних активів.

По-четверте, низький кредитний рейтинг України.

\section{Список використаної літератури:}

1. Лаврушин О.И. Банковское дело: современная система кредитования : учеб. пособ. / О.И. Лаврушин, О.Н. Афанасьева, С.Л. Корниенко ; под ред. заслуж. деят. науки РФ, д.э.н., проф. О.И. Лаврушина. - М. : КНОРУС, 2015. - $256 \mathrm{c}$.

2. Кредитний ризик комерційного банку : навч. посіб. / В.В. Вітлінський, О.В. Пернарівський, Я.С. Наконечний, Г.І. Великоіваненко ; за ред. В.В. Вітлінського. - К. : Знання: КОО, 2010. - 251 с.

3. Ковалев А.П. Кредитный риск-менеджмент : монография / А.П. Ковалев. - К. : Сузір'я, 2017. - 406 с. 
4. Энциклопедия финансового риск-менеджмента / под ред. А.А. Лобанова, А.В. Чугунова. - 3-е изд. - М. : Альпина Бизнес Букс, 2017. - 878 с.

5. Управление деятельностью коммерческого банка (банковский менеджмент) / под ред. д.э.н., проф. О.И. Лаврушина. - М. : Юристь, 2013. - 688 с.

6. Примостка Л.О. Фінансовий менеджмент у банку : підруч. / Л.О. Примостка. - 2-ге вид., доп. і перероб. K. : КHEУ, 2004. $-468 \mathrm{c}$.

7. Prestbo J. Portfolio diversification is still the best investment strategy / J.Prestbo [Електронний ресурс] - Режим доступу : http://www.marketwatch.com/story/portfolio-diversification-is-still-the-best-investment-strategy.

8. Strahan P.E. Bank Diversification, Economic Diversification? / P.E. Strahan // FRBSF Economic Letter. - 2016. № $10 .-4 \mathrm{p}$.

9. Markowitz H.M. Portfolio Selection / H.M. Markowitz // Journal of Finance. - 1952. - № 7. - P. 77-91.

10. Markowitz H.M. Portfolio Selection: Efficient Diversification of Investments / H.M. Markowitz. - London : Chapman \& Hall, Limited ; New York, John Wiley \& Sons, Inc., 1959. - 356 p.

11. Saunders A. Credit Risk Measurement. New Approaches to Value at Risk and Other Paradigms / A.Saunders. New York : John Wiley \& Sons, Inc., 2015. - 319 p.

12. Acharya V.A. Should Banks Be Diversified? Evidence from Individual Bank Loan Portfolios / V.A. Acharya // Journal of Business. - 2016. - № 3. - P. 1355-1412.

13. Acharya V.A. Theory of systemic risk and design of prudential bank regulation / V.A. Acharya // Working paper London Business School. - 2017, January. - № 9. - P. 224-255.

14. Hayden E. Does Diversification Improve the Performance of German Banks? Evidence from Individual Bank Loan Portfolios / E.Hayden. - Wien : Österreichische Nationalbank, 2016.

15. Грошово-кредитна та фінансова статистика НБУ - 2019. - № 12 [Електронний ресурс] - Режим доступу : http://bank.gov.ua.

16. Боди 3. Финансы / З.Боди ; пер. с англ. - М. : Издательский дом «Фильямс», 2013. - 592 с.

17. Гринько О.Л. Управління кредитним ризиком банку на основі методу диверсифікації / О.Л. Гринько // Світ фінансів. - 2018. - № 3. - С. 99-105.

18. Синки Дж. Управление финансами в коммерческих банках / Дж.Синки ; пер. с англ. - М. : Catallaxy, 1994. $820 \mathrm{c}$.

19. Бобиль В. Сек'юритизація банківських активів у контексті управління портфельним кредитним ризиком / В.Бобиль, М.Соловей // Вісник НБУ. - 2010. - № 1. - С. 22-25.

20. Ковалев А. Секьюритизация - финансовая инновация в Украине / А.Ковалев // Финансовый директор. 2016. - № 11. - C. 46-53.

21. ISDA Margin Survey 007 [Електронний ресурс]. - Режим доступу : http://www.isda.org/c_and_a/.

22. Голов С.Ф. Бухгалтерський облік і фінансова звітність за міжнародними стандартами / С.Ф. Голов. - Х. : Фактор, 2017. - $976 \mathrm{c}$.

23. Fender I. The future of securitization: how to align incentives? / I.Fender, J.Mitchell // BIS Quarterly Review. 2019. - № 9. - P. 27-43.

24. Секьюритизация ипотеки: мировой опыт, структурирование и анализ / Э.Девидсон, Э.Сандерс, Л.Вольф, А. Чинг. - М. : Вершина, 2017. - 592 с.

25. Секьюритизация в России: пути развития рынка и снижения стоимости заимствований / Доклад рабочей группы Международной финансовой корпорации. - Вашингтон : Департамент глобальных финансовых рынков, 2015. - 84 с.

26. Версаль Н. Сек’юритизація та ії роль у відновленні фінансової стабільності / Н.Версаль // Вісник НБУ. 2010. - № 4. - C. 28-35.

\section{References:}

1. Lavrushin, O.I., Afanas'eva, O.N. and Kornienko, S.L. (2015), Bankovskoe delo: sovremennaya sistema kreditovaniya, ucheb. posob., in Lavrushin, O.I. (ed.), KNORUS, Moskva, 256 p.

2. Vitlins'kyj, V.V., Pernarivs'kyj, O.V., Nakonechnyj, Ja.S. and Velykoivanenko, G.I. (2010), Kredytnyj ryzyk komercijnogo banku, navch. posib., in Vitlins'kij, V.V. (ed.), Znannja: KOO, Kyiv, 251 p.

3. Kovalev, A.P. (2017), Kreditnyi risk-menedzhment, monografiya, Suzir'ja, Kyiv, 406 p.

4. Lobanov, A.A. and Chugunov, A.V. (ed.), (2017), Entsiklopediya finansovogo risk-menedzhmenta, 3th edition, Al'pina Biznes Buks, Moskva, 878 p.

5. Lavrushin, O.I. (ed.), (2013), Upravlenie deyatel'nost'yu kommercheskogo banka (bankovskii menedzhment), Yurist", Moskva, 688 p.

6. Prymostka, L.O. (2004), Finansovyj menedzhment u banku, pidruch., 2th edition, dop. i pererob., KNEU, Kyiv, 468 p.

7. Prestbo, J., «Portfolio diversification is still the best investment strategy», [Online], available at: http://www.marketwatch.com/story/portfolio-diversification-is-still-the-best-investment-strategy

8. Strahan, P.E. (2016), «Bank Diversification, Economic Diversification?», FRBSF Economic Letter, No. 10, 4 p.

9. Markowitz, H.M. (1952), «Portfolio Selection», Journal of Finance, No. 7, pp. 77-91.

10. Markowitz, H.M. (1959), Portfolio Selection: Efficient Diversification of Investments, Chapman \& Hall, Limited, John Wiley \& Sons, Inc., London, New York, 356 p.

11. Saunders, A. (2015), Credit Risk Measurement. New Approaches to Value at Risk and Other Paradigms, John Wiley \& Sons, Inc., New York, 319 p.

12. Acharya, V. (2016), «Should Banks Be Diversified? Evidence from Individual Bank Loan Portfolios», Journal of Business, No. 3, pp. 1355-1412. 
13. Acharya, V.A. (2017), «Theory of systemic risk and design of prudential bank regulation», Working paper London Business School, January, No. 9, pp. 224-255.

14. Hayden, E. (2016), Does Diversification Improve the Performance of German Banks? Evidence from Individual Bank Loan Portfolios, Österreichische Nationalbank, Wien.

15. NBU (2019), Groshovo-kredytna ta finansova statystyka NBU, No. 12, [Online], available at: http://bank.gov.ua

16. Bodi, Z. (2013), Finansy, transl. by English, Izdatel'skii dom «Fil'yams», Moskva, 592 p.

17. Gryn'ko, O.L. (2018), «Upravlinnja kredytnym ryzykom banku na osnovi metodu dyversyfikacii'», Svit finansiv, No. 3, pp. 99-105

18. Sinki, Dzh. (1994), Upravlenie finansami v kommercheskikh bankakh, transl. by English, Catallaxy, Moskva, 820 p.

19. Bobyl', V. and Solovej, M. (2010), «Sek'jurytyzacija bankivs'kyh aktyviv u konteksti upravlinnja portfel'nym kredytnym ryzykom», Visnyk NBU, No. 1, pp. 22-25.

20. Kovalev, A. (2016), «Sek'yuritizatsiya - finansovaya innovatsiya v Ukraine», Finansovyi direktor, No. 11, pp. 46-53.

21. ISDA Margin Survey 007, [Online], available at: http://www.isda.org/c_and_a/

22. Golov, S.F. (2017), Buhgalters'kyj oblik i finansova zvitnist' za mizhnarodnymy standartamy, Faktor, Harkiv, 976 p.

23. Fender, I. and Mitchell, J. (2019), «The future of securitization: how to align incentives?», BIS Quarterly Review, No. 9, pp. 27-43.

24. Devidson, E., Sanders, E., Vol'f, L. and Ching, A. (2017), Sek'yuritizatsiya ipoteki: mirovoi opyt, strukturirovanie i analiz, Vershina, Moskva, $592 \mathrm{p}$

25. Departament global'nykh finansovykh rynkov (2015), Sek'yuritizatsiya v Rossii: puti razvitiya rynka i snizheniya stoimosti zaimstvovanii, doklad rabochei gruppy Mezhdunarodnoi finansovoi korporatsii, Vashington, $84 \mathrm{p}$.

26. Versal', N. (2010), «Sek'jurytyzacija ta i'i' rol' u vidnovlenni finansovoi' stabil'nosti», Visnyk NBU, No. 4, pp. 28-35.

Лисенок Олексій Володимирович - доктор економічних наук, професор Національного університету харчових технологій.

Наукові інтереси:

- управління фінансово-економічною діяльністю банків;

- управління банківськими ризиками;

- аналіз банківської діяльності. 